\title{
Edukacja uczniów z niepełnosprawnością sprzężoną w Republice Czeskiej
}

\begin{abstract}
Tomasz Kasprzak, Edukacja uczniów z niepetnosprawnościa sprzężona $w$ Republice Czeskiej [Education of students with disabilities coupled in the Czech Republic]. Interdyscyplinarne Konteksty Pedagogiki Specjalnej, nr 22, Poznań 2018. Pp. 289-304. Adam Mickiewicz University Press. ISSN 2300-391X. DOI: https://doi. org/10.14746/ikps.2018.22.16

Currently, recognition of the right of all people to education is considered completely natural. Since the mid-1990s, in the Czech Republic, the issue of educating people with conjugated disability has been increasingly addressed. The main purpose of this study is to characterize the approach to education of people with conjugated disability in the Czech Republic. The article contains interpretations of the concept of conjugate disability, both in native literature and foreign language literature, with particular emphasis on the Czech approach.
\end{abstract}

KEY WORDS: disability coupled. Czech Republic, early intervention, education system

\section{Wprowadzanie}

Edukacja uczniów z niepełnosprawnością sprzężoną tak w Polsce, jak i Republice Czeskiej na przestrzeni ostatnich 20 lat uległa zdecydowanej zmianie. Problematyka edukacji uczniów z niepełnosprawnością od początku lat 90. ubiegłego wieku znajdowała się w polu zainteresowań czeskich pedagogów specjalnych reformujących sferę edukacji. Wcześniej uczniów niepełnosprawnych kształ- 
cono w placówkach ogólnodostępnych, były to jednak, jak podkreśla Zenon Gajdzica, formy integracji naturalnej i często ukrytej. Nie łączyły się one z instytucjonalnym wsparciem, a ich przyczyną bardzo często był brak placówki specjalnej w okolicy zamieszkania ucznia1. Zastanawiając się nad zagadnieniem edukacji uczniów z niepełnosprawnością sprzężoną, należy ustalić czym dany typ niepełnosprawności jest $\mathrm{w}$ istocie $\mathrm{i}$ jakie mogą być zasadnicze potrzeby w obszarze kształcenia, wychowania czy wspomagania rozwoju². Sprzężona niepełnosprawność jest przedmiotem zainteresowań nauk medycznych i nauk o zdrowiu, społecznych (psychologii, pedagogiki specjalnej, socjologii) oraz prawnych (prawa) ${ }^{3}$.

Zarówno w literaturze polskiej, jak i czeskiej istnieją różne sposoby nazywania niepełnosprawności sprzężonej oraz jej definiowania. Możemy się spotkać z terminami takimi jak: „niepełnosprawność wieloraka” (cz. vícenásobne postiženî), „połączona niepełnosprawność" (cz. kombinované postiženî). Jak podkreśla Marzenna Zaorska4, analizując dylemat niepełnosprawności sprzężonej, należy uwzględnić kilka kwestii: „jakościowo odmiennego charakteru niepełnosprawności sprzężonej, który polega na powstaniu, w sytuacji sprzęgania się konkretnych uszkodzeń, stanu jakościowo odmiennego, od stanu, który powoduje w rezultacie obecność jednego z uszkodzeń tworzących niepełnosprawność sprzężoną"5. Autorka przez niepełnosprawność sprzężoną rozumie „[...] stan, z wyłączeniem stanu niepełnosprawności intelektualnej, charakteryzujący się

${ }^{1}$ Z. Gajdzica, Opinie polskich $i$ czeskich nauczycieli na temat przemian ksztatcenia uczniów niepetnosprawnych intelektualnie, „Człowiek - Niepełnosprawność - Społeczeństwo" 2012, nr 15.

${ }^{2}$ M. Zaorska, Aktualne problemy edukacji i rehabilitacji osób z niepetnosprawnościa sprzężoną. „Niepełnosprawność. Tyflosurdopedagogiczne konteksty edukacji i rehabilitacji" 2012, nr 7, s. 9.

${ }^{3}$ B. Marcinkowska, Sprzężona niepetnosprawność - próba analizy fenomenu, „Niepełnosprawność. Dyskursy pedagogiki specjalnej" 2016, nr 21, s. 10.

${ }^{4}$ M. Zaorska, Aktualne problemy edukacji..., s. 9.

${ }^{5}$ M. Zaorska, Psychopedagogiczne uwarunkowania specjalnej edukacji i terapii osób z niepetnosprawnościa sprzężona, "Człowiek - Niepełnosprawność - Społeczeństwo" 2013, nr 1, s. 64. 
obecnością minimum dwóch poważnych wad w budowie organizmu ludzkiego" 6 .

Trudności definicyjne istoty niepełnosprawności sprzężonej wynikają z faktu, ,że [...] nie jest ona prostą sumą składających się na nią niepełnosprawności, ale stanowi swoistą, odrębną złożoną jednostkę"7. Populacja osób z niepełnosprawnością sprzężoną stanowi bardzo zróżnicowaną grupę ze względu na współwystępowanie różnych rodzajów i stopni składających się na nią niepełnosprawności, a wypracowanie jednej (modelowej) charakterystyki osoby z niepełnosprawnością sprzężoną nie jest możliwe ${ }^{8}$.

$\mathrm{Na}$ przestrzeni ostatnich kilku lat w czeskiej literaturze przedmiotu kształcenie uczniów z niepełnosprawnością sprzężoną należy do tematów często podejmowanych. Rozważania teoretyczne i badania koncentrowały się głównie na uczniach głuchoniewidomych. Nad zagadnieniem edukacji uczniów z niepełnosprawnością sprzężoną koncentrowali się czescy pedagodzy i psycholodzy ${ }^{9}$. W literaturze czeskiej możemy znaleźć m.in. definicję, która mówi, że niepełnosprawność sprzężona dotyczy „osoby dotkniętej dwoma lub więcej wadami w tym samym czasie"10. Maria Vítková uważa, że niepełnosprawność sprzężona jest całością ludzkich ograniczeń, we wszystkich sferach doświadczeń i możliwościach ekspresji. Zdolności emocjonalne, poznawcze, fizyczne, a także społeczne i komunikacyjne, zostają znacznie zredukowane i zmienione ${ }^{11}$.

Mając powyższe na uwadze, niniejszy artykuł stawia sobie dwa podstawowe cele. Po pierwsze jest próba usystematyzowania pod-

6 Ibidem, s. 64.

7 A. Twardowski, Pedagogika osób ze sprzężonymi upośledzeniami, [w:] Pedagogika specjalna, red. W. Dykcik, Wydawnictwo Naukowe UAM, Poznań 2006, s. 290.

8 B. Marcinkowska, Wczesne wspomaganie rozwoju dziecka z niepetnosprawnościa sprzężona, [w:] Wczesne wspomaganie rozwoju dziecka z uszkodzonym wzrokiem $i$ dodatkowymi niepetnosprawnościami, red. G. Walczak, MENiS, Warszawa 2005.

${ }^{9}$ Ludiková 2001, 2001; Souralová 2000; Hlaváčová 2003; Vítková 2004; Opatřilová 2005.

${ }^{10}$ M. Sovák, Defektologický slovník (3. vydání), Nakladatelství H\&H, Jínočany 2000, s. 158.

11 M. Vítková, Integrationí speciální pedagogika: Integrace školní a speciální (2. rozšířené a přepracované vzdání), Paido, Brno 2004, s. 325. 
stawowej wiedzy na temat edukacji dzieci i młodzieży z niepełnosprawnością sprzężoną, ustalenia jej głównych kierunków przemian w Republice Czeskiej. Szczególną uwagę zwracam w nim na aspekty prawne edukacji uczniów z niepełnosprawnością sprzężoną, odwołując się przede wszystkim do czeskich ustaw o kształceniu specjalnym. Stąd interesuje mnie to, w jaki sposób tworzony jest proces kształcenia uczniów z niepełnosprawnością sprzężoną. Drugi cel pracy ma charakter teoretyczny. Podkreślane są podstawowe zadania oraz problemy edukacji tych uczniów w czeskich warunkach nauczania. Wybór Republiki Czeskiej jako kraju wynikał zasadniczo z dwóch powodów. Po pierwsze, Republika Czeska należy do grupy krajów dwusystemowych (ang. two-track), w którym drogi uczniów pełnosprawnych i niepełnosprawnych są wyraźnie oddzielone - tylko 3\% uczniów uznawanych za niepełnosprawnych uczęszcza do szkół specjalnych ${ }^{12}$. Po drugie, spoglądając na historię państwa czeskiego, można stwierdzić, iż posiada rozbudowaną sieć szkół specjalnych z długą tradycją opieki i wychowania osób z niepełnosprawnością sprzężoną.

Artykuł podzielony jest na trzy zasadnicze części. W pierwszej analizuje koncepcję edukacji uczniów z niepełnosprawnością sprzężoną (obszary procesu kształcenia / zadania edukacji / edukacyjne kategorie niepełnosprawności sprzężonej). W drugiej części omawiam system edukacji uczniów z niepełnosprawnością sprzężoną w Republice Czeskiej, koncentrując się na ustawie nr 82/2015 Dz.U. (ustawa szkolna). Trzecia część poświęcona jest wczesnej interwencji dzieci ze sprzężoną niepełnosprawnością.

\section{Edukacja uczniów z niepełnosprawnością sprzężoną - podstawowe założenia}

Edukacja definiowana jest jako ogół działań oświatowo-wychowawczych, obejmujących kształcenie i wychowanie, jest procesem

${ }^{12}$ G. Szumski, Integracyjne ksztatcenie niepetnosprawnych, Wydawnictwo Naukowe PWN, Warszawa 2009. 
złożonym ${ }^{13}$. Osoby z niepełnosprawnością sprzężoną funkcjonowały w różnych społeczeństwach od zarania dziejów ludzkości. Mimo to, przez stulecia instytucje specjalne podejmowały jedynie problematykę opieki, rehabilitacji i edukacji osób z niepełnosprawnością jednorodną. Osobom z niepełnosprawnością sprzężoną nie poświęcano należytej uwagi, a nie na płaszczyźnie rozważań teoretycznych ani praktycznych ${ }^{14}$. Wyjątkowy i złożony charakter niepełnosprawności sprzężonej sprawia, że dzieci takie wymagają wyjątkowej, przeważnie specjalnej i wysoce specjalistycznej pomocy. Marzenna Zaorska ${ }^{15}$ podkreśla, że nie chodzi wyłącznie o dostosowanie treści edukacyjnych, organizacji kształcenia czy form pomocy psychologiczno-pedagogicznej, ale przede wszystkim o zrozumienie istoty danej niepełnosprawności i ewentualnych oczekiwań dotyczących oceny efektywności rozwoju ucznia i edukacji ukierunkowanej na ucznia z niepełnosprawnością sprzężoną. Maria Vítková16 wyróżnia trzy obszary, które należy uwzględnić w tworzeniu procesy kształcenia uczniów z niepełnosprawnością sprzężoną:

- Analiza obecnej sytuacji, która jest określona przez wpływ rodziców, warunki materialne rodziny. Ważne jest, aby uzyskać informacje od osób, które opiekowały się dzieckiem do tej pory. Należy zwrócić uwagę na obszary zachowań dziecka (percepcja, rozwój społeczny, emocjonalność, integracja sensoryczno-motoroyczna) oraz podstawowe sytuacje życiowe.

- Określenie celu, którym najważniejszym jest zapewnienie podstawowych potrzeb dziecka, a następnie, w zależności od okoliczności, ustalenie dalszych wymagań

- Przydzielenie specjalnych środków pedagogicznych.

13 W. Okoń, Nowy stownik pedagogiczny, Wydawnictwo Żak, Warszawa 2007, s. 93.

${ }^{14}$ M. Zaorska, Rehabilitacja i edukacja osób z niepetnosprawnościa sprzężona w kontekście historycznym i stan obecny, [w:] Historyczne dyskursy nad pedagogiką specjalną, red. J. Błeszczyński, D. Baczała, J. Binnebesela, Wydawnictwo HAMAL, Łódź 2008, s. 79.

15 M. Zaorska, Niepetnosprawności sprzężone w obliczu aktualnych przemian w systemowych rozwiązaniach edukacyjnych, „Niepełnosprawność. Dyskursy pedagogiki specjalnej" 2014, nr 14, s. 104.

16 Vítková M., Integrationí speciální pedagogika: Integrace školní a speciální (2. rozšířené a přepracované vzdání), Paido, Brno 2004. 
Podstawowym celem edukacji uczniów z niepełnosprawnością sprzężoną jest wzmocnienie zdolności i umiejętności osiągnięcia możliwie najwyższego stopnia samowystarczalności i niezależności w życiu codziennym. Kształcenie powinno być oparte na ograniczonych możliwościach niepełnosprawnego dziecka, szanować jego potrzeby i umiejętności. Dagmara Opatřilová17 wymienia główne zadania edukacji dzieci z niepełnosprawnością sprzężoną:

- optymalny rozwój osobowości dziecka z poszanowaniem różnić indywidualnych każdego dziecka;

- osiągnięcie pożądanego poziomu wykształcenia, spełniający określony stopień socjalizacji dziecka;

- rozwijanie i dostosowywanie potrzeb edukacyjnych do specyfiki niepełnosprawności.

Štefan Vašek ${ }^{18}$ podkreśla, że podstawowym celem edukacji uczniów z niepełnosprawnością sprzężoną jest szczególnie zwiększona ostrożność w podejściu indywidualnym, specjalnych metodach oraz modyfikowaniu treści kształcenia, w odniesieniu do uczniów z pojedynczą niepełnosprawnością. Alicia Vančová ${ }^{19}$ definiuje dwie kategorie niepełnosprawności sprzężonej, opierając się na rodzaju niepełnosprawności, konsekwencjach dla rozwoju osobowości i socjalizacji oraz potrzeb specjalnego wsparcia edukacyjnego ${ }^{20}$ :

- Lekka niepełnosprawność sprzężona: grupa osób, która jest w stanie uzyskać taki poziom wykształcenia, aby móc w pełni rozpocząć aktywność zawodową lub korzystać z zatrudnienia wspomaganego. Edukacja odbywa się przede wszystkim w ogólnodostępnych szkołach podstawowych. Z niewielką pomocą lub bez niej, osoby powinny przystosować się do samodzielnego i niezależnego życia.

17 D. Opatřilová, Metody práce ujedniců s těžkým a více vadami, nakladatelství Masarykova univerzita, Brno 2005.

18 Š. Vašek, A. Vančová, G. Hatos, Pedagogika viacnásobne postihnutých, Sapientia, Bratislava 1999, s. 4.

19 A. Vančová, Edukácia viacnásobne postihnutých, Sapientia, Bratislava 2001.

20 Autorka podkreśla, że nie wszystkie rodzaje niepełnosprawności sprzężonej mogą zostać zakwalifikowane do jednej z tej kategorii. 
- Ciężka niepełnosprawność sprzężona: obejmuje osoby o wyższym poziomie specjalnego wsparcia w zakresie edukacji i rehabilitacji. Proces nauczania odbywa się głównie w szkole specjalnej, często należy go zredukować do elementarnych treści, zgodnie z indywidualnymi umiejętnościami danej osoby. Konieczne jest stosowanie alternatywnych i wspomagających metod porozumiewania się.

Realizowane w Republice Czeskiej działania dotyczące strategii kształcenia uczniów z niepełnosprawnością sprzężoną na poszczególnych etapach ich drogi edukacyjnej, koncentrują się na wyborze jako pożądanej i popieranej edukacji ogólnodostępnej lub integracyjnej. Obecnie można zauważyć silną tendencję do integracji osób niepełnosprawnych w edukacji. Podejście segregacyjne ustępuje miejsca integracji oraz inkluzji mającej przede wszystkim na celu włączenie uczniów ze sprzężoną niepełnosprawnością w szkolne środowisko, i dać im tym samym, lepsze perspektywy na przyszłość.

\section{System edukacji osób z niepełnosprawnością sprzężoną w Republice Czeskiej}

Obecnie Republika Czeska przechodzi dynamiczne przemiany w obszarze praktyki i teorii pedagogiki specjalnej wobec osób z niepełnosprawnością sprzężoną. Działania na rzecz osób niepełnosprawnych są wspierane przez władze państwowe przy ścisłej współpracy z organizacjami pozarządowymi. Cechą czeskiego modelu edukacji uczniów z niepełnosprawnością sprzężoną jest relatywnie wysoki poziom instytucjonalizacji działań, będących konsekwencją utworzenia w 1993 r. Komitetu Rządowego ds. Osób Niepełnosprawnych (cz. Vládní výbor pro zdravotně postižené občany), który regularnie włącza się w koordynowanie inicjatyw mających na celu poprawę sytuacji społecznej, prawnej i ekonomicznej osób niepełnosprawnych w tym kraju. Warto też zaznaczyć, że dzięki wsparciu ze strony Komitetu Rządowego, w Republice Czeskiej regularnie od 1992 r. tworzy nowe Krajowe plany pomocy osobom niepełnospraw- 
nym. Ostatni - Krajowy plan pomocy tworzenia równych szans dla osób niepełnosprawnych na lata 2015-2020 (Národní plán podpory rovných př́ležitostí pro osoby se zdravotním postižením na období 2015-2020), ma na celu promowanie i wspieranie integracji osób niepełnosprawnych oraz podejmowanie działań mających na celu realizowanie Konwencji o prawach osób niepełnosprawnych ${ }^{21}$.

W Republice Czeskiej podstawowym dokumentem, który gwarantuje prawo do opieki i kształcenia, jest Konstytucja. W art. 1 konstytucji czeskiej możemy przeczytać o prawach i swobodzie człowieka i obywatela, a w art. 10 czytamy, że wszystkie ratyfikowane i ogłoszone umowy międzynarodowe o prawach i podstawowych wolnościach człowieka, które wiążą Republikę Czeską, są bezpośrednio obowiązujące i mają pierwszeństwo przed ustawą22.

Problematyka edukacji dzieci z niepełnosprawnością sprzężoną zajmuje szczególne miejsce we współczesnej koncepcji kształcenia specjalnego w Republice Czeskiej. W latach 80. ubiegłego wieku dzieci z niepełnosprawnością sprzężoną zostały zwolnione z obowiązku szkolnego i umieszczane były w placówkach opieki społecznej. Na początku lat 90. XX w. zaszły wyraźne zmiany legislacyjne modyfikujące postawy prawne kształcenia uczniów z niepełnosprawnością sprzężoną. We współczesnej koncepcji dostępu do edukacji osób z niepełnosprawnością sprzężoną, odchodzi się od teorii wad pierwotnych i wtórnych czeskiego profesora Miloša Sováka, na rzecz tzw. „efektu synergicznego” (cz. synergickém efektu) - dziecko przydzielone jest do systemu edukacji i rehabilitacji zgodnie ze stopniem niepełnosprawności. Uwzględniany jest także rodzaj niepełnosprawności, który najbardziej ogranicza indywidualny rozwój dziecka.

21 T. Kasprzak, Specyficzny rodzaj niepetnosprawności jako sytuacja trudna w rodzinie. Osoby gtuchoniewidome $i$ ich rodziny w Republice Czeskiej, "Rodzina wieloproblemowa. Roczniki Socjologii Rodziny. Studia socjologiczne i interdyscyplinarne" 2017, tom XXVI-XXVII, s. 168-174.

22 M. Bełza, System edukacji dzieci niepetnosprawnych intelektualnie w Republice Czeskiej, [w:] Człowiek ze specjalnymi potrzebami w przestrzeni edukacyjnej, społecznej Polski i Republiki Czeskiej, red. Z. Gajdzica, I. Bieńskowska, Oficyna Wydawnicza "Impuls”, Kraków-Katowice 2012, s. 28. 
Charakterystyka niepełnosprawności sprzężonej podana została w 1997 roku w Biuletynie Ministerstwa Edukacji, Młodzieży i Sportu Republiki Czeskiej. Czytamy w nim, że „uczeń z niepełnosprawnością sprzężoną uważany jest wówczas, gdy dotknięty jest dwoma lub więcej przyczynowymi i niezależnymi rodzajami niepełnosprawności, które ze względu ich głębokość i konsekwencje, uprawniają do włączenia go w system kształcenia specjalnego"23. Dla potrzeb czeskiego systemu edukacyjnego, uczniowie z niepełnosprawnością sprzężoną podzieleni są na trzy grupy24:

- pierwsza grupa, w której niepełnosprawność intelektualna jest dominująca $\mathrm{w}$ decyzji o sposobie nauczania, stanowi czynnik decydujący o poziomie wykształcenia;

- druga grupa składa się z kombinacji niepełnosprawności fizycznej, sensorycznej i zaburzeń mowy. Określona grupa w większości składa się z dzieci głuchoniewidomych;

- trzecia grupa składa się z uczniów z diagnozą autyzmu/cechami autystycznymi.

W 2011 r. w specjalnych ośrodkach pedagogicznych zdiagnozowano 17589 uczniów ze sprzężoną niepełnosprawnością. Najczęściej występujące rodzaje niepełnosprawności sprzężonej to: niepełnosprawność intelektualna + zaburzenia komunikacji językowej (6173 uczniów); niepełnosprawność intelektualna + niepełnosprawność ruchowa (5510 uczniów); zaburzenia komunikacji językowej + niepełnosprawność ruchowa (3316 uczniów) ${ }^{25}$. Do najważniejszych aktów prawnych, oprócz konstytucji czeskiej, regulujących edukację dzieci z niepełnosprawnością sprzężoną należą:

- Ustawa nr 82/2015 Dz.U. w sprawie kształcenia przedszkolnego, średniego wyższego i zawodowego i innego - Ustawa szkolna (cz. o předškolním, základnim, středním, vyšším odborném a jiném vzdělávání - školský zákon) oraz następujące rozporządzenia;

23 Věstník MSMT CR č. 8/1997, č.j. 25602/97-22.

24 Vítková M., Integrativní speciální pedagogika: Integrace školní a speciální (2. rozšířené a přepracované vzdání), Paido, Brno 2004.

25 J. Voženílek, J. Michalík, Atlas činnosti speciálněpedagogických center $v$ ČR, Vydavatelstvi Univerzita Palackého v Olomouci, Olomouc 2013, s. 103. 
- Dekret z dnia 2 czerwca 2016r. zmieniające zarządzenie nr. 72/2005 Sb. o udzielaniu w szkołach poradnictwa szkolnego (cz. Výhláška ze dne 2 čerona 2016 kterou se měni výhlaška č. 72?2005 Sb. o poskytování poradenských služeb ve školách a školských poradenských zažizeních);

- Dekret nr 27/2016 Dz.U. w sprawie edukacji dzieci, uczniów i studentów ze specjalnymi potrzebami edukacyjnymi oraz uzdolnionych uczniów (cz. Výhlaška c. 27/2016 Sb. o vzdelávání žákuse specialnimí vzdelávacími potrěbamí a žákunadáných).

Obowiązek szkolny w Republice Czeskiej obejmuje wszystkie dzieci od szóstego roku życia i trwa dziewięć lat (cz. Zákon 561/2004 Sb. o předškolním, základním, středním, vyšším odborném a jiném vzdělávání - školský zákon). Szkoła podstawowa dzieli się na dwa etapy: klasy I-V oraz VI-IX (nauka trwa dziewięć lat). Uczeń z niepełnosprawnością sprzężoną, u którego występuje niepełnosprawność sprzężona, na wniosek opiekuna prawnego oraz pisemnej rekomendacji poradni psychologiczno-pedagogicznej kształcony jest w szkole specjalnej. Natomiast uczniowie z niepełnosprawnością sprzężoną, u których nie występuje niepełnosprawność intelektualna, są kształceni w szkołach ogólnodostępnych lub szkołach specjalnych, które odpowiadają potrzebom wynikającym z posiadania dwóch lub więcej niepełnosprawności.

Wreszcie trzeba wspomnieć o specjalistycznych formach wsparcia - przede wszystkim dla rodzin uczniów z niepełnosprawnością sprzężoną. To dwa typy placówek, funkcjonujące w szkołach, takie jak: poradnia psychologiczno-pedagogiczna (cz. pedagogicko-psychologická poradna) oraz specjalne centra pedagogiczne (cz. speciálně pedagogické centrum). Ich podstawowym celem jest nieodpłatne zapewnienie opieki pedagogicznej na wniosek rodziców lub prawnych opiekunów ucznia26.

Różnorodność, indywidualność i specjalne potrzeby edukacyjne uczniów z niepełnosprawnością sprzężoną są przyczyną szczegóło-

26 Vyhláška 116/2011 Sb., o poskytování služeb ve školách a školských poradenských zařízeních. 
wego zaplanowania ich edukacji. Konieczne jest zatem opracowanie szczegółowego indywidualnego planu edukacyjnego (cz. individuální vzdělávací plán) dla każdego ucznia. Zgodnie z dekretem nr 27/2016 Dz.U. w sprawie edukacji dzieci, uczniów i studentów ze specjalnymi potrzebami edukacyjnymi oraz uzdolnionych uczniów, dyrektor szkoły może, za pisemnym zaleceniem szkolnego centrum doradztwa, zatwierdzić indywidualny plan edukacyjny dla ucznia $\mathrm{z}$ niepełnosprawnością sprzężoną, który jest dokumentem wiążącym, zapewniającym:

- informację na temat treści, zakresu, przebiegu i sposobu świadczenia specjalnej opieki pedagogicznej;

- informację na temat realizacji celów kształcenia, treści programów nauczania, wyboru procedur pedagogicznych, sposobu oceny ucznia;

- listę zajęć kompensacyjnych, rehabilitacyjnych oraz pomocy dydaktycznych;

- asystenta nauczyciela, który w szczególność zapewnia: pomoc w dostosowaniu się uczniów do środowiska szkolnego, pomoc w komunikowaniu się ucznia z nauczycielami, pomoc $\mathrm{w}$ czynnościach samoobsługowych;

- uczniowi wsparcia za pomocą systemu komunikacji innego niż język mówiony. Szkoła zapewnia system komunikacyjny, który spełnia potrzeby ucznia;

- tłumacza czeskiego języka migowego. Tłumacz wykorzystywany jest przez cały czas trwania lekcji, a także podczas apeli, wycieczek czy zajęć pozalekcyjnych organizowanych przez szkołę.

Indywidualny plan edukacyjny sporządza się bez zbędnej zwłoki, jednak nie później niż miesiąc od daty otrzymania przez szkołę wniosku od prawnego opiekuna ucznia. Plan edukacyjny może być uzupełniany i dostosowywany do potrzeb ucznia przez cały rok szkolny. Dyrektor szkoły odpowiedzialny jest za opracowanie i wdrożenie indywidualnego planu edukacyjnego. Plan opracowywany jest we współpracy z placówką doradztwa szkolnego, uczniem i jego 
prawnymi opiekunami, jeśli uczeń jest niepełnoletni. Placówka doradztwa szkolnego we współpracy $\mathrm{z}$ nauczycielami co najmniej raz w roku ocenia realizację planu edukacyjnego. Dekret 27/2016 Dz.U. (cz. vyhláška č. 27/2016 Sb., o vzdeláváni žáku se speciálními vzdelávacími potrěbami a žáku nadaných) zapewnia kształcenie uczniów z niepełnosprawnością sprzężoną poprzez:

- integrację w klasach szkół podstawowych lub szkołach przeznaczonych dla uczniów z różnymi rodzajami niepełnosprawności na podstawie indywidualnego planu edukacyjnego;

- utworzenie klasy dla uczniów z niepełnosprawnością sprzężoną w szkole specjalnej;

- utworzenie klasy dla uczniów niepełnosprawnych w zwykłej szkole lub szkole specjalnej dla uczniów z innymi rodzajami niepełnosprawności.

Asystent nauczyciela (cz. Asistent pedagoga) jest pracownikiem pedagogicznym zajmującym się edukacją dzieci, uczniów i studentów o specjalnych potrzebach edukacyjnych, jeśli nie są w stanie skutecznie zaspokoić swoich potrzeb. Podstawowymi zadaniami asystenta nauczyciela są: (1) możliwość indywidualnej pracy z uczniem, (2) tworzenie warunków pracy zespołowej, (3) wspieranie ucznia niezdolnego do pełnego zaangażowania się podczas zajęć lekcyjnych.

\section{Wczesna interwencja (raná péče) dzieci ze sprzężoną niepełnosprawnością w Republice Czeskiej}

Problem wczesnej interwencji (cz. raná péče) wobec dzieci z niepełnosprawnością, jako tendencja działań na rzecz normalizacji życia i integracji, pojawiła się na świecie w latach 70. XX w. W Republice Czeskiej za początek działań na rzecz upowszechniania koncepcji można uznać lata 90. XX w., kiedy z inicjatywy Teresy Hradlikovej, Barbary Kašovej, Teresy Sklemickovej i Jana Vachulova, pod kierownictwem profesora Oldřicha Č́leka, stworzono wsparcie dla rodziców dzieci z wadami wzroku. Pojawiło się podej- 
ście, w którym brane jest pod uwagę zarówno dziecko, jak i jego rodziców oraz innych członków rodziny. Czeski model wczesnej interwencji opiera się na zasadzie "towarzyszenia" (cz. provazeni) i zbudowany jest na trzech podstawowych filarach: (1) wsparcie rozwoju dziecka, (2) wsparcie rodziny, (3) wspieranie integracji dziecka i rodziny ze społeczeństwem.

Oldřich Matoušek wczesną interwencję definiuje jako „zestaw połączonych usług społecznych, zdrowotnych i psychologicznych. Przeznaczony jest dla dzieci $\mathrm{w}$ wieku przedszkolnym, u których pojawiająca się niepełnosprawność poważnie zagraża jego rozwojowi. Interwencja obejmuje dzieci, jak i ich rodziny i odbywa się w naturalnym środowisku dziecka" 27 . Wczesna interwencja w czeskim prawodawstwie rozumiana jest jako terenowa praca socjalna, a pracownik socjalny działa bezpośrednio $\mathrm{w}$ terenie. Legislacyjnie wczesna interwencja uznana jest za usługę społeczną, a odpowiedzialność za jej realizację należy do Ministerstwa Pracy i Spraw Socjalnych na podstawie ustawy $\mathrm{nr}$ 108/2006 Dz.U. o usługach socjalnych, z późniejszymi zmianami (cz. Zákon č. 108/2006 Sb.o sociálních službách). Ustawa definiuje wczesną interwencję jako opiekę terenową lub/i ambulatoryjną świadczoną dziecku poniżej siódmego roku życia i jego rodzinie.

Działania $\mathrm{w}$ ramach wczesnej interwencji skierowane są do dwóch grup dzieci i ich rodzin ${ }^{28}$ :

- od wykrycia niepełnosprawności (wraz z wiekiem prenatalnym) do czterech lat dla dzieci z niepełnosprawnością zdrowotną lub zagrożonych niepełnosprawnością,

- od wykrycia niepełnosprawności (wraz z wiekiem prenatalnym) do siedmiu lat dla dzieci z zaburzeniami sprzężonymi, sensorycznymi, fizycznymi i intelektualnymi.

27 O. Matoušek, Metody a ř́zení sociální práce (wydanie drugie), Portál, Praha 2008, s. 168.

28 S. Wrona, Wczesna interwencja - rozwiazania polskie i czeskie, [w:] Człowiek ze specjalnymi potrzebami w przestrzeni edukacyjnej i społecznej Polski oraz Republiki Czeskiej, red. Z. Gajdzica, I. Bieńkowska, Oficyna Wydawnicza „Impuls”, KrakówKatowice 2012, s. 57. 
Wczesna interwencja koncentruje się przede wszystkim na wykryciu niepełnosprawności, profilaktyce oraz stymulowaniu rozwoju. Obejmuje wszystkie rodzaje interwencji, które są potrzebne we wczesnych latach życia dziecka. Istotne jest, aby wiedzieć, w jaki sposób potencjał dziecka z niepełnosprawnością sprzężoną może być wykorzystywany nie tylko dla jego osobistego rozwoju, ale także dla zwiększenia jego uczestnictwa w społeczeństwie. Należy zatem poszukiwać odpowiednich metod integracji społecznej i edukacyjnej. Jak wskazuje Josef Slowik, wczesna interwencja nie ocenia wad dziecka i ograniczeń, ale przeciwnie, koncentruje się na jego pozytywnych możliwościach. Autor podkreśla, że $\mathrm{w}$ przypadku dziecka $\mathrm{z}$ niepełnosprawnością (także sprzężoną), należy zachowywać się tak, jakby było zdrowym dzieckiem - nie próbować pokazywać wyjątkowości jego niepełnosprawności, unikać współczucia czy frustracji związanej z losem dziecka ${ }^{29}$. Klientem wczesnej interwencji jest rodzina, a rodzice są partnerami zespołu. Interwencja odbywa się głównie w środowisku domowym dziecka. System rodzinny traktowany jest jako złożona i zintegrowana całość. Szacunek dla indywidualności dziecka, jego wyjątkowości kulturowej, społecznej i edukacyjnej stanowi fundament wczesnej interwencji w Republice Czeskiej ${ }^{30}$.

Praca $\mathrm{z}$ rodzicami dzieci $\mathrm{z}$ niepełnosprawnością sprzężoną (konsultacje, poradnictwo społeczne i edukacyjne, tworzenie strategii komunikacji alternatywnej i wspomagającej, pomoc w wyborze przedszkola czy szkoły specjalnej) nie różni się od pracy z innymi rodzinami. Każda rodzina ma prawo do takiej samej ilości czasu czy informacji. Każdy $\mathrm{z}$ problemów dziecka $\mathrm{z}$ niepełnosprawnością sprzężoną musi być rozwiązywany osobno.

\section{Podsumowanie}

Obecny system edukacji uczniów z niepełnosprawnością sprzężoną powstał na początku lat. 90. XX w., aby umożliwić realizację

29 J. Slowík, Speciální pedagogika, Grada Publishing a.s, Praha 2007, s. 151.

30 T. Hradliková, Raná péče pro rodiny s dětmi se zrakovým postižením a kombinovaným postižením, Středisko rené péče, Praha 1998. 
obowiązku szkolnego przez tych uczniów. W Republice Czeskiej kształcenie uczniów ze sprzężoną niepełnosprawnością może być realizowane $\mathrm{w}$ systemie segregacyjnym (historycznie najstarszym), a także, może mieć również formę nauczania indywidualnego. Cele formułowane w obrębie kształcenia uczniów z niepełnosprawnością sprzężoną ukierunkowane są na wyposażenie ich w możliwie najpełniejsze kompetencje. W społeczeństwie czeskim problematyka aktywności edukacyjnej uczniów z niepełnosprawnością sprzężoną budzi zainteresowanie i troskę wśród badaczy. Znaczącą pomoc dla uczniów z niepełnosprawnością sprzężoną i ich rodziców stwarzają poradnie psychologiczno-pedagogiczne oraz specjalne centra pedagogiczne. Uczniowie $\mathrm{z}$ niepełnosprawnością sprzężoną stanowią bardzo zróżnicowaną grupę, dlatego stopień i forma procesu kształcenia musi być indywidualna.

\section{Bibliografia}

Bełza M., System edukacji dzieci niepetnosprawnych intelektualnie w Republice Czeskiej, [w:] Człowiek ze specjalnymi potrzebami w przestrzeni edukacyjnej, spotecznej Polski $i$ Republiki Czeskiej, red. Z. Gajdzica, I. Bieńskowska, Oficyna Wydawnicza „Impuls", Kraków-Katowice 2012.

Gajdzica Z., Opinie polskich i czeskich nauczycieli na temat przemian ksztatcenia uczniów niepetnosprawnych intelektualnie, "Człowiek - Niepełnosprawność - Społeczeństwo" 2012, nr 15.

Hradliková T., Raná péče pro rodiny s dětmi se zrakovým postižením a kombinovaným postižením, Středisko rené péče, Praha 1998.

Kasprzak T., Specyficzny rodzaj niepetnosprawności jako sytuacja trudna w rodzinie. Osoby gtuchoniewidome $i$ ich rodziny w Republice Czeskiej, "Rodzina wieloproblemowa. Roczniki Socjologii Rodziny. Studia socjologiczne i interdyscyplinarne" 2017, tom XXVI-XXVII.

Marcinkowska B., Wczesne wspomaganie rozwoju dziecka z niepetnosprawnościa sprzężona, [w:] Wczesne wspomaganie rozwoju dziecka $z$ uszkodzonym wzrokiem i dodatkowymi niepetnosprawnościami, red. G. Walczak, MENiS, Warszawa 2005.

Matoušek O., Metody a řízení sociální práce (wydanie drugie), Portál, Praha 2008.

Marcinkowska B., Sprzężona niepetnosprawność - próba analizy fenomenu, „Niepełnosprawność. Dyskursy pedagogiki specjalnej" 2016, nr 21.

Okoń W., Nowy słownik pedagogiczny, Wydawnictwo Żak, Warszawa 2007. 
Opatřilová D., Metody práce ujedniců s těžkým a více vadami, nakladatelství Masarykova univerzita, Brno 2005.

Slowík J., Speciální pedagogika, Grada Publishing a.s, Praha 2007.

Sovák M., Defektologický slovník (3. vydání), Nakladatelství H\&H, Jínočany 2000.

Szumski G., Integracyjne ksztatcenie niepetnosprawnych, Wydawnictwo Naukowe PWN, Warszawa 2009.

Twardowski A., Pedagogika osób ze sprzężonymi upośledzeniami, [w:] Pedagogika specjalna, red. W. Dykcik, Wydawnictwo Naukowe UAM, Poznań 2006.

Wrona S., Wczesna interwencja - rozwiazania polskie i czeskie, [w:] Człowiek ze specjalnymi potrzebami w przestrzeni edukacyjnej i społecznej Polski oraz Republiki Czeskiej, red. Z. Gajdzica, I. Bieńkowska, Oficyna Wydawnicza „Impuls”, Kraków - Katowice 2012.

Zaorska M., Rehabilitacja i edukacja osób z niepetnosprawnościq sprzężona w kontekście historycznym i stan obecny, [w:] Historyczne dyskursy nad pedagogika specjalna, red. J. Błeszczyński, D. Baczała, J. Binnebesela, Wydawnictwo HAMAL, Łódź 2008.

Zaorska M., Aktualne problemy edukacji i rehabilitacji osób z niepetnosprawnością sprzeżona. „Niepełnosprawność. Tyflosurdopedagogiczne konteksty edukacji i rehabilitacji" 2012, nr 7.

Zaorska M., Psychopedagogiczne uwarunkowania specjalnej edukacji i terapii osób z niepetnosprawnościa sprzężona, "Człowiek - Niepełnosprawność - Społeczeństwo" 2013, nr 1.

Vančová A., Edukácia viacnásobne postihnutých, Sapientia, Bratislava 2001.

Vašek Š., Vančová A., Hatos G., Pedagogika viacnásobne postihnutých, Sapientia, Bratislava 1999.

Vítková M., Integrationí speciální pedagogika: Integrace školní a speciální (2. rozšířené a přepracované vzdání), Paido, Brno 2004.

Voženílek J., Michalík J., Atlas činnosti speciálněpedagogických center v ČR, Vydavatelstvi Univerzita Palackého v Olomouci, Olomouc 2013. 